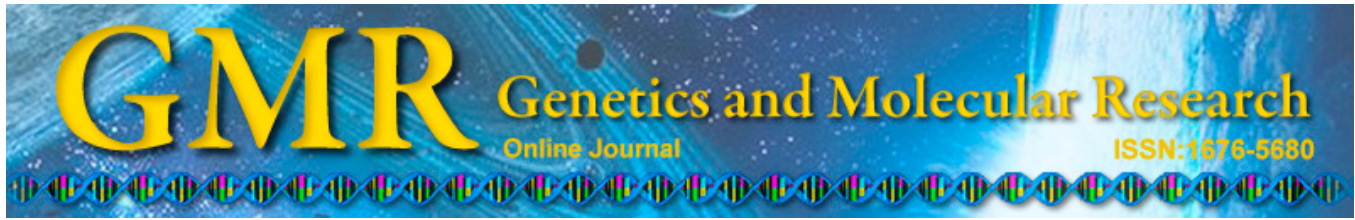

\title{
Microsatellite in Aeschynomene falcata (Leguminosae): diversity, cross-amplification, and chromosome localization
}

C.A. Polido ${ }^{1,3}$, C.C. Mantello ${ }^{2}$, A.P. Moraes ${ }^{1,4}$, A.P. Souza ${ }^{1,2}$ and

E.R. Forni-Martins ${ }^{1}$

${ }^{1}$ Programa de Pós-Graduação em Biologia Vegetal, Departamento de Biologia Vegetal, Instituto de Biologia, Universidade Estadual de Campinas, Campinas, SP, Brasil ${ }^{2}$ Centro de Biologia Molecular e Engenharia Genética, Universidade Estadual de Campinas, Campinas, SP, Brasil ${ }^{3}$ Escolas e Faculdade MAGSUL, Ponta Porã, MS, Brasil

${ }^{4}$ Departamento de Genética, Instituto de Biociências, Universidade Estadual Paulista Júlio de Mesquita Filho, Botucatu, SP, Brasil

Corresponding author: A.P. Moraes

E-mail: apaulademoraes@gmail.com

Genet. Mol. Res. 13 (4): 10390-10397 (2014)

Received April 8, 2014

Accepted August 8, 2014

Published December 4, 2014

DOI http://dx.doi.org/10.4238/2014.December.4.34

ABSTRACT. Aeschynomene falcata is an important forage species; however, because of low seed production, it is underutilized as forage species. Aeschynomene is a polyphyletic genus with a challenging taxonomic position. Two subgenera have been proposed, and it is suggested that Aeschynomene can be split in 2 genera. Thus, new markers, such as microsatellite sequences, are desirable for improving breeding programs for A. falcata. Based on transferability and in situ localization, these microsatellite sequences can be applied as chromosome markers in the genus Aeschynomene and closely related genera. Here, we report the first microsatellite library developed for this genus; 11 microsatellites were characterized, with observed and 
expected heterozygosities ranging from 0.0000 to 0.7143 and from 0.1287 to 0.8360 , respectively. Polymorphic information content varied from 0.1167 to 0.7786 . The departure from Hardy-Weinberg equilibrium may have resulted from frequent autogamy, which is characteristic of A. falcata. Of the 11 microsatellites, 9 loci were cross-amplified in $A$. brevipes and A. paniculata and 7 in Dalbergia nigra and Machaerium vestitum. Five of these 7 cross-amplified microsatellites were applied as probes during the in situ hybridization assay and 2 showed clear signals on A. falcata chromosomes, ensuring their viability as chromosome markers.

Key words: Cross-amplification; Fluorescence in situ hybridization; Forage; Microsatellite

\section{INTRODUCTION}

Aeschynomene falcata (Poir.) DC. (Leguminosae) is an important forage species with high persistence, resistance to intensive grazing, and tolerance to low-fertile soils. However, the seeds are not produced in sufficient quantities for marketing because of low fertility (Jones et al., 2000). Productivity may be increased through plant breeding techniques, which may contribute to the development of molecular markers, which are useful for assaying genetic variation. Microsatellite markers, or simple sequences repeats (SSRs), are effective for planning crosses in breeding programs (Ruiz and Asins, 2003; Flajoulot et al., 2005). In addition to their low cost, SSRs are hypervariable, present codominant heritage, show reproducible results, have chromosome-specific locations, and show high transferability (Kalia et al., 2011).

SSR cross-amplification is a potential source of variation for evolutionary and taxonomic studies, with the SSR transfer rate corresponding to taxonomic distance (Ellis and Burke, 2007; Pinheiro et al., 2009). This approach may be helpful for studying the Dalbergia clade, in which Aeschynomene genus is included. The Dalbergia clade position in the Papilionoideae phylogeny is well-understood (Cardoso et al., 2012); however, its internal resolution has not been well-defined. Among its taxonomic problems is the genus Aeschynomene, which is split into 2 groups (Ribeiro et al., 2007), including Aeschynomene subgen. Ochopodium (monophyletic with Dalbergia and Machaerium) and Aeschynomene subgen. Aeschynomene. Some authors have suggested that the subgen. Ochopodium should be placed in another genus. Morphological, molecular, and chromosome markers have been applied for the Dalbergia clade, but the resolution of Aeschynomene remains obscure (Klitgaard and Lavin, 2005; Ribeiro et al., 2007; Queiroz and Cardoso, 2008; Polido, 2013). Taking advantage of the chromosomespecific location and transferability of SSR, we developed new chromosome markers using the microsatellite library as a source of probes for in situ localization. This approach was previously applied for Orchidaceae (Begum et al., 2009), in which 3 new chromosome markers were identified and used to determine species relatedness to the Dendrobium genus.

We developed and characterized a microsatellite library for A. falcata (subgen Ochopodium) for future applications in both breeding systems and taxonomy studies. Cross-amplification, as well as in situ hybridization, were tested in A. brevipes Benth., A. paniculata Willd. ex Vogel (both subgen. Ochopodium), Dalbergia nigra (Vell.) German ex Benth., and Machaerium vestitum Vogel. 


\section{MATERIAL AND METHODS}

\section{Plant collection DNA extraction}

Individuals from 2 populations of $A$. falcata and from one population of $A$. brevipes, A. paniculata, D. nigra, and M. vestitum were collected in São Paulo State and Mato Grosso do Sul State. Specimen vouchers were deposited in the UEC and CGMS Herbarium. Additional information for the populations and voucher are shown in Table 1. Genomic DNA was extracted using the DNeasy Plant Mini Kit (Qiagen, Hilden, Germany).

\begin{tabular}{|c|c|c|c|c|}
\hline Species & Geographical location & Latitude & Longitude & Voucher No. \\
\hline \multirow[t]{2}{*}{ Aeschynomene falcata } & Passos, Minas Gerais State, Brazil & $20^{\circ} 49^{\prime} 17^{\prime \prime S}$ & $46^{\circ} 37^{\prime} 01^{\prime \prime} \mathrm{W}$ & UEC 148660 \\
\hline & Porto Murtinho, Mato Grosso do Sul State, Brazil & $21^{\circ} 41^{\prime} 50^{\prime \prime} \mathrm{S}$ & $57^{\circ} 41^{\prime} 17^{\prime \prime} \mathrm{W}$ & CGMS 19860 \\
\hline A. brevipes & Porto Murtinho, Mato Grosso do Sul State, Brazil & $21^{\circ} 41^{\prime} 50^{\prime \prime} \mathrm{S}$ & $57^{\circ} 41^{\prime} 17^{\prime \prime} \mathrm{W}$ & CGMS 19828 \\
\hline A. paniculata & Campinas, São Paulo State, Brazil & $22^{\circ} 48^{\prime} 53^{\prime \prime S}$ & $47^{\circ} 05^{\prime} 46^{\prime \prime} \mathrm{W}$ & UEC 169750 \\
\hline Dalbergia nigra & Campinas, São Paulo State, Brazil & $22^{\circ} 48^{\prime} 53^{\prime \prime} \mathrm{S}$ & $47^{\circ} 04^{\prime} 02^{\prime \prime} \mathrm{W}$ & UEC 169748 \\
\hline Machaerium vestitum & Campinas, São Paulo State, Brazil & $22^{\circ} 48^{\prime} 53^{\prime \prime} \mathrm{S}$ & $47^{\circ} 04^{\prime} 02^{\prime \prime} \mathrm{W}$ & UEC 169749 \\
\hline
\end{tabular}

CGMS = Herbarium of the Universidade Federal de Mato Grosso do Sul; UEC = Herbarium of the Universidade Estadual de Campinas

\section{Microsatellite-enriched library construction and sequencing}

A microsatellite-enriched genomic library was obtained for A. falcata, according to Billotte et al. (1999). Enrichment was performed using a hybridization-based capture with $(\mathrm{GT})_{8}$ and $(\mathrm{CT})_{8}$, biotin-linked probes, and streptavidin magnetic-coated beads. A total of 56 selected recombinant colonies were bidirectionally sequenced using an automated ABI PRISM 377 sequencer (Applied Biosystems, Foster City, CA, USA) with T7 and SP6 primers and the BigDye Terminator v3.1 Cycle Sequencing Kit (Life Technologies, Carlsbad, CA, USA). Sequences were aligned and edited using the Seqman program (DNASTAR, Madison, WI, USA). Microsatellite regions were identified and characterized using the program Gramene (Temnykh et al., 2001). As a criterion for SSR selection, sequences showing at least 5 dinucleotide repeats, 4 trinucleotide repeats, and 3 tetra-, penta-, and hexanucleotide repeats were selected. The primer pairs were designed using the PrimerSelect software (DNASTAR) and microsatellite loci were amplified by polymerase chain reaction performed in a $20 \mu \mathrm{L}$ total volume containing $15 \mathrm{ng}$ template DNA, 1 X PCR buffer, $2 \mathrm{mM} \mathrm{MgCl}_{2}, 8 \mathrm{mM}$ dNTPs, $0.04 \%$ bovine serum albumin, $0.5 \mathrm{mM}$ each forward and reverse primer, and $0.5 \mathrm{U}$ Taq DNA polymerase. A Bio-Rad C1000 ${ }^{\mathrm{TM}}$ Thermal Cycler (Hercules, CA, USA) was used for the amplification reaction with the following program: an initial denaturation at $94^{\circ} \mathrm{C}$ for $2 \mathrm{~min} ; 2 \mathrm{X}$ 10 cycles $\left(-1^{\circ} \mathrm{C}\right.$ per cycle) at 3 different temperatures of touchdown, $65^{\circ}-55^{\circ} \mathrm{C}, 60^{\circ}-50^{\circ} \mathrm{C}$, and $55^{\circ}-45^{\circ} \mathrm{C}\left(94^{\circ} \mathrm{C}\right.$ for $1 \mathrm{~min}, 65^{\circ} \mathrm{C}, 60^{\circ}$ or $55^{\circ} \mathrm{C}$ for $1 \mathrm{~min}$, and $72^{\circ} \mathrm{C}$ for $\left.2 \mathrm{~min}\right)$, followed by 18 cycles $\left(94^{\circ} \mathrm{C}\right.$ for $1 \mathrm{~min}, 55^{\circ} \mathrm{C}, 50^{\circ}$ or $45^{\circ} \mathrm{C}$ for $1 \mathrm{~min}$, and $72^{\circ} \mathrm{C}$ for $2 \mathrm{~min}$ ), and a final extension of $72^{\circ} \mathrm{C}$ for $5 \mathrm{~min}$. Amplification products were analyzed by electrophoresis on $3 \%$ agarose gels stained with ethidium bromide and were genotyped using a $6 \%$ denaturing polyacrylamide gel stained with silver nitrate (Creste et al., 2001) and the genotyper Advance FS96. Because of the low number of individuals of 2 populations of A. falcata (Minas Gerais State, 12 individuals; Mato Grosso do Sul State, 3 individuals), the 2 different populations 
were statistically analyzed together. Analysis of expected and observed heterozygosities were performed using the TFPGA software (Miller, 1997), the polymorphism information content was determined using Pic Calculator (Kemp, 2002), and Hardy-Weinberg equilibrium tests for each locus were calculated using Genepop available online (Rousset, 2008).

\section{Fluorescence in situ hybridization (FISH)}

Roots from all material were pretreated in $0.002 \mathrm{M}$ solution of 8-hydroxyquinoline for 20-24 $\mathrm{h}$ at $10^{\circ} \mathrm{C}$ and then fixed in 3:1 absolute ethanol: glacial acetic acid (v:v) for 20-24 $\mathrm{h}$ at room temperature; samples were stored at $-20^{\circ} \mathrm{C}$.

The chromosome preparation and the in situ hybridization followed the method described by Moraes et al. (2012). Five SSR were used as probes: Aesfal.1 (monomorphic), Aesfal.8 (monomorphic in one region/polymorphic in another region), Aesfal.10 and Aesfal.13 (2 polymorphic regions each), and Aesfal.11 (polymorphic). The probes were labeled by nick translation (Roche, Basel, Switzerland) using Cy-3 (Invitrogen, Carlsbad, CA, USA). After 1 $\mathrm{h}$ incubation in $1 \%$ RNase, slides were treated with pronase-E for $10 \mathrm{~min}$ and fixed in $4 \%$ paraformaldehyde for $10 \mathrm{~min}$. In situ hybridization was performed at $77 \%$ stringency and slides were mounted with DAPI-Vectashield (Vector Labs, Burlingame, CA, USA). The slides were analyzed and photographed under a Leica DM2500 fluorescent microscope (Solms, Germany) coupled with a DFC360 FX camera and images were acquired using the LAS 3.6 software (Media Cybernetics, Inc., Rockville, MD, USA).

\section{RESULTS AND DISCUSSION}

\section{Microsatellite sequences-polymorphism and transferability}

A total of 23 primer pairs were designed and 11 were amplified in A. falcata (Table 1), 7 of which were polymorphic. A total of 38 alleles were identified, ranging from 1 to 7 alleles per locus, with a mean of 3.45 . The observed and expected heterozygosities ranged from 0.0000 to 0.7143 and from 0.1287 to 0.8360 , respectively, while the polymorphism information content varied from 0.1167 to 0.7786 (Table 2). Hardy-Weinberg Equilibrium was calculated for 6 of the 11 SSR developed and deviation from the equilibrium was detected, which was likely caused by the autogamous crossing of this species.

\section{Polymorphism and heterozygosity}

Of these 11 amplified loci, 9 were amplified in A. brevipes and A. paniculata. Of these loci, 6 amplified in both D. nigra and M. vestitum, plus another unique locus in each species (Table 3). The 11 markers and cross-amplification for the other 2 genera, Dalbergia e Machaerium, confirmed that all would be useful for future breeding programs.

Two microsatellite loci (Aesfal.8 and Aesfal.10) showed more than 1 region of amplification. Aesfal.8 locus presented a monomorphic region (approximately 147 base pairs) for all species, whereas a polymorphic region was present only in the A. falcata sample. The Aesfal.10 locus presented 2 polymorphic regions, 1 exclusive for $A$. falcata and the other observed only in related species. 
C.A. Polido et al.

10394

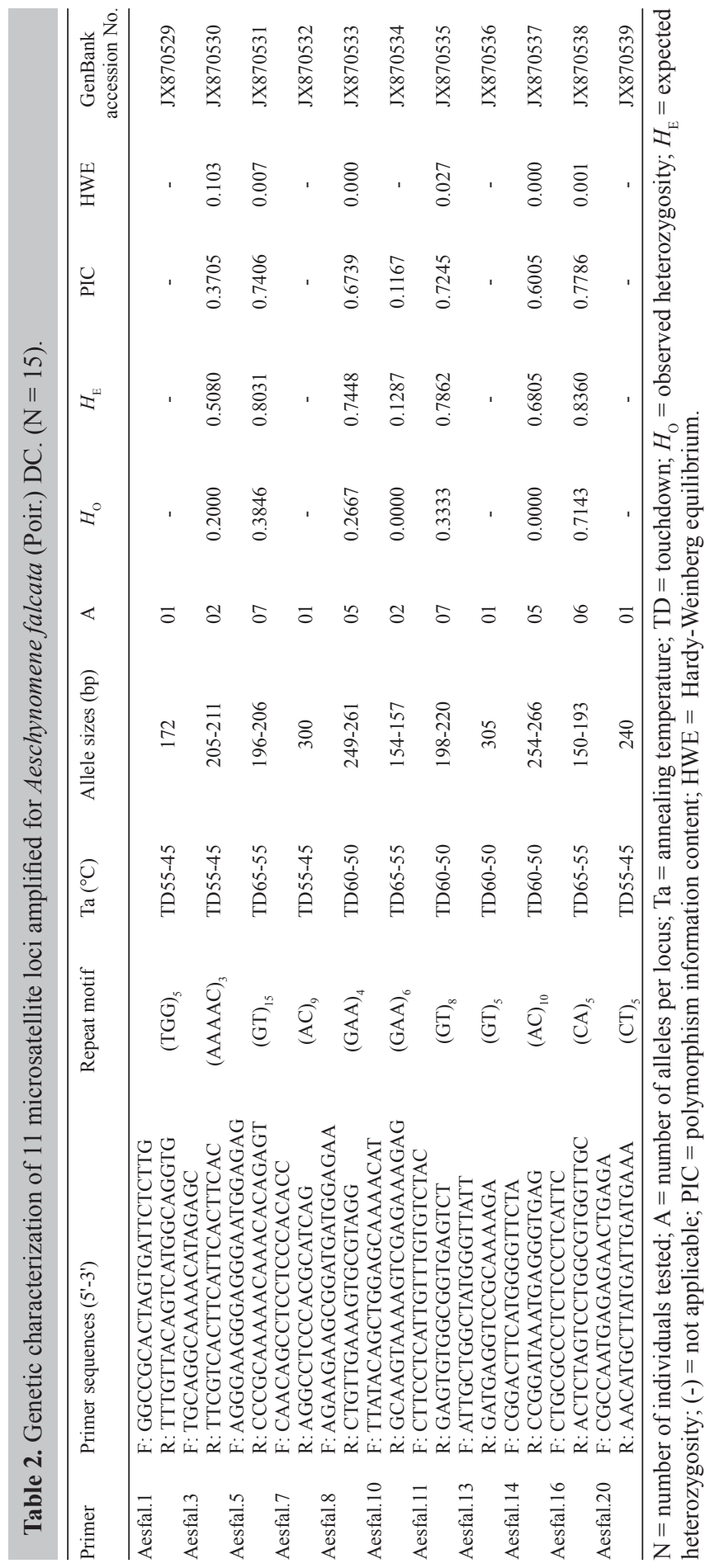

Genetics and Molecular Research 13 (4): 10390-10397 (2014)

CFUNPEC-RP www.funpecrp.com.br 
Table 3. Microsatellite loci of Aeschynomene falcata tested for cross-amplification in 14 individuals of four species.

\begin{tabular}{lcccc}
\hline Primer & $\begin{array}{c}\text { Aeschynomene brevipes } \\
(\mathrm{N}=5)\end{array}$ & $\begin{array}{c}\text { Aeschynomene paniculata } \\
(\mathrm{N}=5)\end{array}$ & $\begin{array}{c}\text { Dalbergia nigra } \\
(\mathrm{N}=2)\end{array}$ & $\begin{array}{c}\text { Machaerium vestitum } \\
(\mathrm{N}=2)\end{array}$ \\
\hline Aesfal.1 & + & + & + & - \\
Aesfal.3 & - & - & - & - \\
Aesfal.5 & + & + & + & - \\
Aesfal.7 & + & + & + & + \\
Aesfal.8 & + & + & + & + \\
Aesfal.10 & + & + & - & + \\
Aesfal.11 & - & - & + & + \\
Aesfal.13 & + & + & - & + \\
Aesfal.14 & + & + & + & + \\
Aesfal.16 & + & + & + & + \\
Aesfal.20 & + & + & + \\
\hline
\end{tabular}

$\mathrm{N}=$ number of individuals tested; "+” = successful amplification; "-" = failed amplification.

\section{In situ localization}

Two of the 5 SSR sequences tested (Aesfal.1 and Aesfal.11) showed a clear signal on the A. falcata chromosomes, each SSR labeling 1 chromosome pair (Figure 1). The remaining 3 SSR sequences were likely below the method limit of detection, preventing the signal visualization. The sensibility limit for in situ location is approximately $1 \mathrm{~kb}$ (Schwarzacher and Heslop-Harrison, 2000) and because microsatellites could be repeated hundreds of times, this value can be above $1 \mathrm{~kb}$, but is frequently below this value. All SSR tested were crossamplified in A. brevipes, A. paniculata, D. nigra, and M. vestitum; however, it was not possible to visualize the sequences on the chromosomes, likely because the sequences were below the method detection capabilities.

In Dendrobium, SSR sequences can also be transferred to close genera, as observed in this study, but the SSR mapped were likely larger than those mapped here as 3 SSR probes from Dendrobium moschatum (Buch.-Ham.) Sw were detected after FISH in close species, as well as in close genera (1 SSR) [Nageliella angustifolia (Booth ex Lindl.) Ames et Correl, Oncidium sphacelatum L. and Phalaenopsis lueddemanniana var. purpurea (Rchb.f.) Sweet.] (Begum et al., 2009).
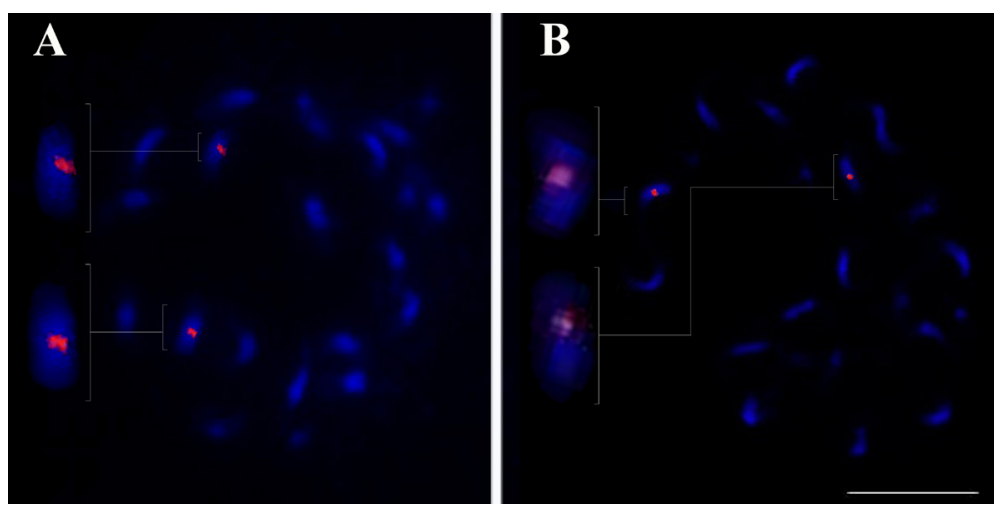

Figure 1. Microsatellite mapping through in situ hybridization in Aeschynomene falcata chromosomes. A. SSR Aesfal.1 and B. SSR Aesfal.11. Barr in B corresponds to $10 \mu \mathrm{m}$. 


\section{CONCLUSIONS}

We developed the first microsatellite library for Aeschynomene, with specific sequences, amplifying only Aeschynomene species, broadly distributed sequences, and the Dalbergia and Machaerium genera. This new SSR library can be used for breeding programs and as a source of new chromosome markers, which is a novel approach in molecular cytogenetics. However, the SSR sequences applied were localized by in situ hybridization only in A. falcata, indicating that they were exclusive chromosome markers. Future studies mapping new SSR probes may reveal new chromosome markers; together with currently used probes, these markers will enable chromosome characterization of Aeschynomene and close genera.

\section{ACKNOWLEDGMENTS}

Research supported by Fundação de Amparo à Pesquisa de São Paulo (FAPESP, Project \#2011/22215-3 to A.P. Moraes and \#2010/19132-6 to E.R. Forni-Martins) and Conselho Nacional de Pesquisa (CNPq, Project \#471708/2010-0). The authors thank F.M. Alves and R.T. Queiroz for sample collection.

\section{REFERENCES}

Begum R, Alam SS, Menzel G and Schmidt T (2009). Comparative molecular cytogenetics of major repetitive sequence families of three Dendrobium species (Orchidaceae) from Bangladesh. Ann. Bot. 104: 863-872.

Billotte N, Lagoda PJR, Risterucci AM and Baurens FC (1999). Microsatellite-enriched libraries: Applied methodology for the development of SSR markers in tropical crops. Fruits 54: 277-288.

Cardoso D, de Queiroz LP, Pennington RT, de Lima HC, et al. (2012). Revisiting the phylogeny of papilionoid legumes: New insights from comprehensively sampled early-branching lineages. Am. J. Bot. 99: 1991-2013.

Creste S, Tulmann Neto A and Figueira A (2001). Detection of single sequence repeat polymorphisms in denaturing polyacrylamide sequencing gels by silver staining. Plant Mol. Biol. Rep. 19: 299-306.

Ellis JR and Burke JM (2007). EST-SSRs as a resource for population genetic analyses. Heredity 99: 125-132.

Flajoulot S, Ronfort J, Baudouin P, Barre P, et al. (2005). Genetic diversity among alfalfa (Medicago sativa) cultivars coming from a breeding program, using SSR markers. Theor. Appl. Genet. 111: 1420-1429.

Jones RM, Mcdonald CK, Clements RJ and Bunch GA (2000). Sown pastures in subcostal south-eastern Queensland: pasture composition, legume persistence and cattle live weight gain over 10 years. Trop. Grassl. 34: 21-37.

Kalia RK, Rai MK, Kalia S, Singh R, et al. (2011). Microsatellite markers: an overview of the recent progress in plants. Euphytica 177: 309-334.

Kemp S (2002). PIC Calculator Extra. Available at [http://www.genomics.liv.ac.uk/animal/pic.html]. Accessed September 4, 2012.

Klitgaard BB and Lavin M (2005). Tribe Dalbergieae Sens. Lat. In: Legumes of the World (Lewis GP, Schrire BD, MacKinder BA and Lock M, eds.). Royal Botanic Gardens, Kew, 307-335.

Miller MP (1997). Tools for Populations Genetics Analyses. V 1.3. A Windows ${ }^{\circledR}$ program for the analysis of allozyme and molecular population genetic data. Available at [http://www.ccg.unam.mx/ vinuesa/tlem09/docs/TFPGADOC. PDF]. Accessed April 4, 2014.

Moraes AP, Leitch IJ and Leitch AR (2012). Chromosome studies in Orchidaceae: karyotype divergence in Neotropical genera in subtribe Maxillariinae. Bot. J. Linn. Soc. 170: 29-39.

Pinheiro F, Palma-Silva C, de BF and Cozzolino S (2009). Cross-amplification and characterization of microsatellite loci for the Neotropical orchid genus Epidendrum. Genet. Mol. Biol. 32: 337-339.

Polido C (2013). Estudo Cromossômico da Tribo Dalbergieae Sensu Klitgaard \& Lavin (2005), com Ênfase no Clado Dalbergia Sensu Stricto (Leguminosae, Papilionoideae). Doctoral thesis, Universidade Estadual de Campinas, Campinas.

Queiroz L and Cardoso DBOS (2008). A new species of Aeschynomene L. (Leguminosae, Papilionoideae) from a continental sand dune area in north-eastern Brazil. Bot. J. Linn. Soc. 157: 749-753. 
Ribeiro RA, Lavin M, Lemos-Filho JP, Mendonça-Filho CV, et al. (2007). The genus Machaerium (Leguminosae) is more closely related to Aeschynomene sect. Ochopodium than to Dalbergia: inferences from combined sequence data. Syst. Bot. 32: 762-771.

Rousset F (2008). genepop'007: a complete re-implementation of the genepop software for Windows and Linux. Mol. Ecol. Resour. 8: 103-106.

Ruiz C and Asins MJ (2003). Comparison between Poncirus and Citrus genetic linkage maps. Theor. Appl. Genet. 106: 826-836.

Schwarzacher TP and Heslop-Harrison P (2000). Practical in Situ Hybridization. 1st edn. Bios, Oxford.

Temnykh S, DeClerck G, Lukashova A, Lipovich L, et al. (2001). Computational and experimental analysis of microsatellites in rice (Oryza sativa L.): frequency, length variation, transposon associations, and genetic marker potential. Genome Res. 11: 1441-1452.

Thiers B (2014). Index Herbariorum: A global Directory of Public Herbaria and Associated Staff. New York Botanical Garden's Virtual Herbarium. Available at [http://sciweb.nybg.org/science2/IndexHerbariorum.asp]. Accessed April 4, 2014. 